\title{
Growth and production of Heliconia under different light conditions
}

\section{Crescimento e produção de Helicônia sob diferentes condições de luminosidade}

\author{
Mayara Wesley da Silva ${ }^{1 *}$; Elizabeth Orika Ono ${ }^{2}$; Maria Herbênia Lima Cruz \\ Santos $^{3}$; Márkilla Zunete Beckmann Cavalcante ${ }^{4}$; Gertrudes Macário de Oliveira"; \\ Dulce Naiara Carvalho Ferreira ${ }^{6}$; Caio Cesar Lopes ${ }^{7}$
}

\begin{abstract}
The use of shading screens of different colors can change the spectral quality of radiation and, as a consequence, the growth and production of crop plants. The aim of this study was to evaluate aspects of the growth, yield, and quality of floral stems of Heliconia psittacorum $\times H$. spathocircinata 'Golden Torch' grown under different light conditions. The treatments consisted of four conditions: blue photoconversion screens (35\%-40\%); red photoconversion screens (18\%-21\%); black shading screens (45\%-49\%), and full sunlight. The experiment consisted of two parts. In the first, growth was assessed, whereas in the second, aspects related to the production and quality of floral stems were examined. The experimental design was in randomized blocks with split plots in time. Each plot contained six blocks, with 11 replications per block, giving a total of 66 pots per plot. The evaluations were performed at 30 day intervals over a 6-month period. In the analysis of growth, red screens contributed to the growth of the plants, increasing the number of shoots and leaves, and also plant height. The productivity and quality of floral stems was, however, highest in plants grown under blue and black screens. It can be concluded that, under the prevailing experimental conditions, the use of blue screens $(35 \%-40 \%)$ and black screens (45\%-49\%) is suitable for production of the floral stems of 'Golden Torch' heliconia.
\end{abstract}

Key words: Heliconia psittacorum $\times$ H. spathocircinata 'Golden Torch'. Photoconversion screen. Ornamental plant.

\section{Resumo}

O uso de malhas de sombreamento de diferentes cores pode alterar a qualidade espectral da radiação e, como consequência, o crescimento e a produção de uma cultura vegetal. Desta forma, o objetivo do presente trabalho foi avaliar aspectos do crescimento, produção e qualidade das hastes florais de Heliconia psittacorum x H. spathocircinata 'Golden Torch' cultivadas sob diferentes condições de luminosidade. Os tratamentos consistiram em quatro ambientes: malha fotoconversora azul (35-40\%); malha fotoconversora vermelha (18-21\%); malha de sombreamento preta (45-49\%) e pleno sol. O experimento constou de duas partes: na primeira realizaram-se avaliações de crescimento e na segunda,

\footnotetext{
${ }^{1}$ M.e. em Horticultura, Discente de Doutorado, Universidade Federal de Goiás, UFG, Goiânia, GO, Brasil. E-mail: mayarawesley@, hotmail

${ }^{2}$ Prof ${ }^{a}$ Adjunto, Universidade Estadual Paulista, UNESP, Botucatu, SP, Brasil. E-mail: eoono@ibb.unesp.br

3 Prof ${ }^{a}$ Titular, Universidade do Estado da Bahia, UNEB, Juazeiro, BA, Brasil. E-mail: mherbenia@gmail.com

${ }^{4}$ Prof ${ }^{a}$ Adjunto, Universidade Federal do Vale do São Francisco, UNIVASF, PE, Brasil. E-mail: markilla.beckmann@univasf.edu. br

${ }^{5}$ Prof $f^{\mathrm{a}}$ Titular, UNEB, Juazeiro, BA, Brasil. E-mail: gmoliveira@uneb.br

${ }^{6}$ Egresso do Curso de Graduação em Agronomia, UNEB, Juazeiro, BA, Brasil. E-mail: dulceagronomia10@gmail.com

7 Egresso do Curso de Graduação em Agronomia, UNEB, Juazeiro, BA, Brasil. Brasil. E-mail: caiouneb@gmail.com

* Author for correspondence
} 
foram estudados aspectos relacionados à produção e qualidade das hastes florais. $\mathrm{O}$ delineamento experimental foi em blocos casualizados em esquema de parcelas subdivididas no tempo, sendo seis blocos por parcela, cada bloco com onze repetições, totalizando sessenta e seis vasos por parcela. As avaliações foram realizadas durante seis meses, com intervalos de trinta dias. Nas análises de crescimento observou-se que a malha vermelha contribuiu com o crescimento das plantas, incrementando o número de perfilhos, folhas e altura das plantas. A produtividade e a qualidade das hastes florais foi superior em plantas cultivadas sob tela azul e preta. Conclui-se que, nas condições experimentais estabelecidas, o uso das malhas azul (35-40\%) e preta (45-49\%) é indicado para a produção de hastes florais de Heliconia 'Golden Torch'.

Palavras-chave: Heliconia psittacorum x H. spathocircinata 'Golden Torch'. Malha fotoconversora. Ornamentais.

\section{Introduction}

Changes in the quantity and quality of solar radiation influence the growth, morphology, anatomy, and various physiological and biochemical aspects of plants, and also promote changes in flowering and productivity (DAY et al., 2009; CRAVEN et al., 2010; FAVARETTO et al., 2011).

The quality of radiation required for the adequate development of plants is related to the composition of the radiation spectrum, which is composed of different wavelengths. The most important spectral bands with respect to photobiological processes are ultraviolet, visible, and infrared. Several biological processes are influenced by radiation in the visible spectrum, and the main sources of energy that stimulate photosynthesis and photomorphogenic responses lie in this range (HART, 1988; TAIZ; ZEIGER, 2013). Thus manipulation of radiation quantity and quality has been performed via the use of shading and photoconversion/photoselective screens.

Black and gray neutral screens decrease the incidence of radiation at the plant surface, transmit the radiation equally in the range of the visible spectrum, and act as neutral density filters (ORENSHAMIR et al., 2001). Colored photoconversion screens, in addition to providing protection against adverse weather conditions, modulate lighting by modifying the portion of the light spectra that radiates the plant. This enables the control of radiation, in order to facilitate the development of certain specific plant characteristics, including the physiological traits related to variation in the light spectrum (ILIĆ et al., 2012).

The responses of various ornamental plants to changes in radiation quality include the following: extension of the internodes of chrysanthemums grown under blue screens (OYAERT et al., 1999); greater petiole length and leaf area in Anthurium andraeanum cultivated under black shading screens (LIMA et al., 2010); increase in the height of sprouts of Alpinia 'Jungle Queen' and 'Jungle King' grown under red screens (SOUZA, 2012); and increase in the rosette diameter and leaf size of silver vase (Aechmea fasciata) grown under red screens (HOLCMAN; SENTELHAS, 2013).

The demand for heliconia inflorescences has increased in several countries, and this growing popularity has stimulated studies that identify culture traits of interest for the cut flower agribusiness (LOGES, 2012). Thus, in this study, we evaluated the aspects of growth, production, and quality of floral stems of Heliconia psittacorum $\times$ Heliconia spathocircinata 'Golden Torch' under different light conditions.

\section{Material and Methods}

The experiment was conducted between November 2013 and May 2014, in the experimental area of the Department of Technology and Social Sciences (DTCS). Campus III, University of the State of Bahia (UNEB), Juazeiro, Brazil (latitude S $9^{\circ} 25^{\prime} 10^{\prime \prime}$, longitude W 40 $29^{\prime} 16^{\prime \prime}$ and altitude 367 $\mathrm{m})$. 
The plant material used for assessing the production of Heliconia psittacorum $\times H$. spathocircinata 'Golden Torch' was obtained through the division of rhizomes, derived from plants of the flower production area at the same university. At 162 days after planting of propagation units, the plants were transplanted into 18-L black polyethylene pots, in order to also verify the influence of treatments on the root system. The substrate used was composed of fluvisol, sand, and vegetable compost from the company Sanvale Gestão Ambiental ${ }^{\circledR}$, used at a ratio of 1:1:1. Plants were watered daily via a drip irrigation system.

The experimental design was randomized in blocks with split plots in time. Each plot comprised 6 blocks, with 11 replications per block, giving 66 pots per plot and a total of 264 plants. The treatments consisted of four conditions: blue photoconversion shade cloth (ChromatiNet ${ }^{\circledR}$ Blue 35\%-40\%), red photoconversion shade cloth (ChromatiNet ${ }^{\circledR}$ Red 18\%-21\%), black shading screen (Black Mesh 45\%$49 \%$ ), and full sunlight (no cover). Each treatment comprised an area of $10 \mathrm{~m} \times 24 \mathrm{~m}$, height of $3.0 \mathrm{~m}$, and an "umbrella-type" structure closed in one of the sides.

Evaluations were performed at 30-day intervals, over a period of 6 months. Six plants per plot were used for each destructive evaluation. These were removed from the field and transported to the Laboratory of Olericulture at the DTCS-UNEB, where the following assessments were performed: number of stems, number of leaves, leaf area $\left(\mathrm{cm}^{2}\right)$, plant height $(\mathrm{cm})$, dry mass of aerial parts $(\mathrm{g})$, and dry mass of roots + rhizomes. For leaf area measurements, all expanded leaves were removed from the plant and arranged on a bench, where they were photographed. The photographs were processed by the program Quant ${ }^{\circledR}$ version 1.0.1 (VALE et al., 2003). Plant height was measured from the tip of the last expanded leaf up to the point where the psuedostem sheath changes color, using a measuring tape graduated in centimeters. For dry matter measurements, plant parts were placed in a forced air circulation oven at $65^{\circ} \mathrm{C}$ for $72 \mathrm{~h}$. Subsequently, they were weighed using a digital balance and the mass of dry matter calculated.

The following data were also assessed: the number of days from issuance of the stem until the date of collection of floral stems [CYCLE: after the issuance of the stem, we counted the number of days until the inflorescence reached the point of harvest, the latter being indicated by inflorescences bearing two open bracts and a closed clump, according to the methodology described by Criley et al. (2001) and Lamas (2004)]; the number of inflorescences harvested $/ \mathrm{m}^{2}$ (the number of inflorescences collected in an area of one square meter); number of floral stems (NFS: obtained from the count of all the inflorescences produced in 30 replicates during the period of the experiment); flower stem length [FSL $(\mathrm{cm})$ : for the measurement of FSL the flower stem harvested at $2 \mathrm{~cm}$ above soil level was measured using a tape measure from the point of the cut to the base of the inflorescence]; average diameter of the flower stem [FSD ( $\mathrm{mm})$ : the average of the diameter of the base of the flower stem and the diameter of the base of the inflorescence, measured with the aid of a digital pachymeter]; stems with marketing standard [SMS: the quality standard established by Farias (2004) and Albuquerque et al. (2010) was used to determine stems with a length greater than 70 centimeters that do not show any injury or deformation].

Monitoring of the climatic conditions of each experimental environment was achieved through installation of data acquisition systems and temperature and global radiation sensors (radiometers). The sensors were connected to an automatic data collector (CR1000 Micrologger; Campbell Scientific Inc.) powered by a solar panel, which was programmed to perform readings every second and calculate hourly and daily averages.

The data obtained were submitted to analysis of variance, and means were compared using the Tukey test at 5\% significance. A polynomial regression 
analysis was also carried out in relation to the evaluation periods, and the choice of the regression was based on the significance of the coefficient of determination of the equations obtained by the $t$ test.

\section{Results and Discussion}

The production of heliconia was affected by cultivation conditions. There were differences in all characteristics of growth, and also in the number of stems harvested. Changes in performance of plant growth with different color screens were observed, being more pronounced compared to the cultivation in full sunlight. Thus, it can be inferred that the plants of 'Golden Torch' heliconia are sensitive to the intensity and quality of light, and that shading provided by the screens, regardless of percentage and coloring, was beneficial to the development of plants compared to those grown in full sunlight.

With regard to the number of stems of $H$. psittacorum $\times H$. spathocircinata 'Golden Torch', significant differences were observed from the third assessment, at which time plants grown under black screens had a statistically higher number of stems; however, this pattern was not observed for other parameters. At 120 and 180 days of cultivation, the number of stems was higher in plants grown under red screens (Table 1). In contrast to the data obtained in the present study, Meirelles et al. (2007) observed that shading with different screens did not influence the number of shoots of Rhaphis excelsa, whereas Nomura et al. (2009) and Lima et al. (2010) observed that black screens provide better microclimatic conditions for plant growth and production of floral stems of Anthurium andraeanum 'Apalai'.

With regard to the number of leaves, it was observed that at 180 days of cultivation, plants grown under red screens produced more leaves than plants grown under the other types of screen (Table 1). This can be explained by an increase in the red:far red light ratio, provided by red screens, which leads to an increase in the number of leaves in the canopy of plants. Souza (2012), working with Alpinia purpurata, and Kawabata et al. (2007) working with Dracaena deremensis 'Janet Craig' and $D$. marginata, also observed that plants grown under red screens had a higher number of leaves when compared with plants grown under other types of screen.

The larger number of leaves produced by plants grown under red screens, however, did not result in increased leaf area per plant after 120 days of cultivation (Table 1). However, at 150 days of cultivation, plants grown under red screens had a higher leaf area. On the other hand, at 180 days, plants grown under black screens displayed statistical superiority in relation to other conditions. Similar results were obtained by Nomura et al. (2009), who observed that black screens were more efficient in promoting the development of leaf tissue in Anthurium, whereas Gaffney (2004) observed an increase of the total leaf area in croton when grown under red screens. The number of leaves and, consequently the leaf area, is an important variable for the estimation of plant growth, due to the relationship between photosynthesis components and biological plant production. It is assumed that black and red screens provide favorable conditions for photosynthetic processes and, consequently, better vegetative growth of 'Golden Torch' heliconia.

The growth in plant height was also positively affected by the use of shading with screens, since the development of the plants provided with full sunlight was lower throughout the evaluation period (Table 2). Shading provides a greater ratio of farred light, converted into red, which induces plants to allocate most of their metabolites to growth in plant height (TAIZ; ZEIGER, 2013). 
Table 1. Shoot and leaf number and leaf area $\left(\mathrm{cm}^{2}\right)$ of Heliconia psittacorum $\times$ H. spathocircinata 'Golden Torch' at 30, 60, 90, 120,150, and 180 days of cultivation under different conditions (blue screen, red screen, black screen, and full sunlight). Period: November 2013 to May 2014. Juazeiro, BA.

\begin{tabular}{|c|c|c|c|c|c|c|c|c|c|c|c|c|}
\hline & \multicolumn{12}{|c|}{ Days after transplantation } \\
\hline & \multicolumn{2}{|l|}{30} & \multicolumn{2}{|l|}{60} & 90 & & \multicolumn{2}{|l|}{120} & \multicolumn{2}{|l|}{150} & \multicolumn{2}{|l|}{180} \\
\hline & \multicolumn{12}{|c|}{ Shoot number } \\
\hline Blue screen & 2 & $\mathrm{a}$ & 6 & $\mathrm{a}$ & 6.3 & $\mathrm{~b}$ & 8.3 & $\mathrm{ab}$ & 9.3 & $\mathrm{a}$ & 9.8 & $\mathrm{ab}$ \\
\hline Red screen & 2.5 & a & 4.8 & $\mathrm{a}$ & 5.8 & $\mathrm{~b}$ & 9.3 & a & 8.2 & $\mathrm{a}$ & 11.2 & $\mathrm{a}$ \\
\hline Black screen & 2.3 & a & 4.7 & $\mathrm{a}$ & 8.2 & $\mathrm{a}$ & 7.7 & $\mathrm{~b}$ & 9.2 & $\mathrm{a}$ & 9.8 & $a b$ \\
\hline Full sunlight & 2.7 & $\mathrm{a}$ & 5 & $\mathrm{a}$ & 6.2 & $\mathrm{~b}$ & 7.8 & $\mathrm{ab}$ & 9.7 & $\mathrm{a}$ & 8.3 & $\mathrm{~b}$ \\
\hline \multirow{2}{*}{$\mathrm{CV}(\%)$} & & & & & & & 3.01 & & & & & \\
\hline & \multicolumn{10}{|c|}{ Math equation } & \multicolumn{2}{|l|}{$\mathrm{R}^{2}$} \\
\hline Blue screen & \multicolumn{10}{|c|}{$y=0.0487 x+1.8555$} & \multicolumn{2}{|c|}{89.71} \\
\hline Red screen & \multicolumn{10}{|c|}{$\mathrm{y}=0.0541 \mathrm{x}+1.2889$} & \multicolumn{2}{|c|}{91.43} \\
\hline Black screen & \multicolumn{10}{|c|}{$y=0.0481 x+1.9222$} & \multicolumn{2}{|c|}{87.27} \\
\hline \multirow[t]{2}{*}{ Full sunlight } & \multicolumn{10}{|c|}{$\mathrm{y}=-0.0003 \mathrm{x}^{2}+0.1072 \mathrm{x}-0.4000$} & \multicolumn{2}{|c|}{95.12} \\
\hline & \multicolumn{12}{|c|}{ Leaf numbers } \\
\hline Blue screen & 8.6 & $\mathrm{a}$ & 18.4 & $\mathrm{a}$ & 24.6 & $\mathrm{ab}$ & 27.6 & $\mathrm{a}$ & 36.6 & $\mathrm{a}$ & 34 & $\mathrm{~b}$ \\
\hline Red screen & 11.6 & a & 17.2 & $\mathrm{a}$ & 20.4 & bc & 29.2 & a & 36.8 & $\mathrm{a}$ & 42.2 & $\mathrm{a}$ \\
\hline Black screen & 9.6 & a & 16.8 & $\mathrm{a}$ & 29.4 & $\mathrm{a}$ & 28.2 & $\mathrm{a}$ & 29.6 & $\mathrm{~b}$ & 36 & $\mathrm{~b}$ \\
\hline Full sunlight & 10.4 & $\mathrm{a}$ & 18.6 & $\mathrm{a}$ & 19.4 & $\mathrm{c}$ & 26.2 & $\mathrm{a}$ & 32.4 & $\mathrm{ab}$ & 34 & $\mathrm{~b}$ \\
\hline \multirow[t]{2}{*}{$\mathrm{CV}(\%)$} & \multicolumn{12}{|c|}{13.44} \\
\hline & \multicolumn{10}{|c|}{ Math equation } & \multicolumn{2}{|l|}{$\mathrm{R}^{2}$} \\
\hline Blue screen & & & & & $=0.1758 \mathrm{x}$ & $x+6$ & 067 & & & & 90.93 & \\
\hline Red screen & & & & & $=0.2101$ & $x+4$ & 733 & & & & 98.5 & \\
\hline Black screen & & & & & $=0.1611 \mathrm{r}$ & +8 & 133 & & & & 85.9 & \\
\hline Full sunlight & & & & & $=0.1583 \mathrm{x}$ & $x+6$ & 800 & & & & 96.4 & \\
\hline & & & & & & Lea & rea $\left(\mathrm{cm}^{2}\right)$ & & & & & \\
\hline Blue screen & 2034.33 & $\mathrm{a}$ & 1865.09 & $\mathrm{a}$ & 2114.83 & $\mathrm{a}$ & 4463.99 & $\mathrm{a}$ & 3290.55 & $\mathrm{~b}$ & 6796.81 & $\mathrm{~b}$ \\
\hline Red screen & 2238.84 & $\mathrm{a}$ & 2051.96 & $\mathrm{a}$ & 2260.91 & $\mathrm{a}$ & 3458.46 & $\mathrm{a}$ & 5542.72 & $\mathrm{a}$ & 5073.23 & $\mathrm{c}$ \\
\hline Black screen & 1934.62 & $\mathrm{a}$ & 2155.49 & $\mathrm{a}$ & 1774.83 & $\mathrm{a}$ & 3619.26 & $\mathrm{a}$ & 4289.38 & $\mathrm{~b}$ & 7833.97 & $\mathrm{a}$ \\
\hline Full sunlight & 1875.96 & $\mathrm{a}$ & 2069.19 & $\mathrm{a}$ & 2324.23 & $\mathrm{a}$ & 3604.53 & $\mathrm{a}$ & 3945.47 & $\mathrm{~b}$ & 4703.92 & $\mathrm{c}$ \\
\hline $\mathrm{CV}(\%)$ & & & & & & & 4.05 & & & & & \\
\hline & & & & & Math ec & uat & & & & & $\mathrm{R}^{2}$ & \\
\hline Blue screen & & & $y=$ & .25 & $7 x^{2}-23.8$ & 649 & 2497.940 & & & & $81.6^{6}$ & \\
\hline Red screen & & & & & $24.6112 x$ & +85 & 5047 & & & & 80.5 & \\
\hline Black screen & & & $y=c$ & .413 & $1 x^{2}-50.8$ & $115 x$ & 3297.252 & & & & 95.93 & \\
\hline Full sunlight & & & & & $20.0479 x$ & +98 & 1451 & & & & 94.42 & \\
\hline
\end{tabular}

*Means followed by the same letter in the column do not differ significantly, as determined by the Tukey test ( $\mathrm{p}>0.05)$.

The spectral quality of light to which heliconia plants were exposed significantly altered the dry matter mass of aerial parts (Table 2), whereas the accumulation of root + rhizome dry mass was not influenced by the spectrum of light. The latter was, however, positively affected by a reduction in radiation, since plants grown under black screens received the lowest percentage of radiation (Table 2). It was also found that plants grown in full sunlight had a lower mass during the experiment, which may be attributed to the inferior development of the plants. 
Table 2. Height, mass of aerial part dry matter $(\mathrm{g})$, mass of dry matter + rhizome $(\mathrm{g})$ of Heliconia psittacorum $\times H$. spathocircinata 'Golden Torch' at 30, 60, 90, 120, 150, and 180 days of cultivation under different conditions (blue screen, red screen, black screen, and full sunlight). Period: November 2013 to May 2014. Juazeiro, BA

\begin{tabular}{|c|c|c|c|c|c|c|c|c|c|c|c|c|}
\hline \multirow{3}{*}{$\begin{array}{l}\text { Treatments } \\
\end{array}$} & \multicolumn{12}{|c|}{ Days after transplantation } \\
\hline & \multicolumn{2}{|l|}{30} & \multicolumn{2}{|c|}{60} & \multicolumn{2}{|c|}{90} & \multicolumn{2}{|c|}{120} & \multicolumn{2}{|c|}{150} & \multicolumn{2}{|c|}{180} \\
\hline & \multicolumn{12}{|c|}{ Plant height (cm) } \\
\hline Blue screen & 86.4 & $\mathrm{a}$ & 98.2 & $\mathrm{a}$ & 97.4 & $\mathrm{a}$ & 80.6 & $\mathrm{a}$ & 86.2 & $\mathrm{a}$ & 109 & b \\
\hline Red screen & 91.6 & $\mathrm{a}$ & 91.6 & $\mathrm{a}$ & 80.2 & bc & 80.4 & $\mathrm{a}$ & 82.6 & $\mathrm{a}$ & 112 & $\mathrm{~b}$ \\
\hline Black screen & 85.2 & $\mathrm{a}$ & 89 & $a b$ & 86.6 & $a b$ & 79 & $\mathrm{a}$ & 84.8 & $\mathrm{a}$ & 137 & $\mathrm{a}$ \\
\hline Full sunlight & 92.8 & $\mathrm{a}$ & 75 & $\mathrm{~b}$ & 67.6 & $\mathrm{c}$ & 71 & $\mathrm{a}$ & 60.2 & $\mathrm{~b}$ & 109 & $\mathrm{~b}$ \\
\hline \multirow[t]{2}{*}{$\mathrm{CV}(\%)$} & \multicolumn{12}{|c|}{11.98} \\
\hline & \multicolumn{10}{|c|}{ Math equation } & \multicolumn{2}{|c|}{$\mathrm{R}^{2}$} \\
\hline Blue screen & \multicolumn{10}{|c|}{$y=92.7$} & \multicolumn{2}{|c|}{$*_{\mathrm{ns}}$} \\
\hline Red screen & \multicolumn{10}{|c|}{$y=0.0039 x^{2}-0.7675 x+115.78$} & \multicolumn{2}{|c|}{77.04} \\
\hline Black screen & \multicolumn{10}{|c|}{$y=0.0054 x^{2}-0.9208 x+115.62$} & \multicolumn{2}{|c|}{74.05} \\
\hline \multirow[t]{2}{*}{ Full sunlight } & \multicolumn{10}{|c|}{$y=0.0063 x^{2}-1.2927 x+128.50$} & \multicolumn{2}{|c|}{74.84} \\
\hline & \multicolumn{12}{|c|}{ Dry mass of aerial part (g) } \\
\hline Blue screen & 18 & $\mathrm{a}$ & 32.8 & $\mathrm{a}$ & 44.8 & $\mathrm{ab}$ & 56.6 & $\mathrm{a}$ & 75.2 & $\mathrm{a}$ & 72 & $\mathrm{~b}$ \\
\hline Red screen & 27.1 & $\mathrm{a}$ & 25.6 & $a b$ & 32.8 & $\mathrm{~b}$ & 54.6 & $\mathrm{a}$ & 78.4 & $\mathrm{a}$ & 88 & $\mathrm{a}$ \\
\hline Black screen & 19.4 & $\mathrm{a}$ & 26 & $a b$ & 52 & $\mathrm{a}$ & 53.6 & $\mathrm{a}$ & 71.2 & $\mathrm{a}$ & 94 & $\mathrm{a}$ \\
\hline Full sunlight & 19.6 & $\mathrm{a}$ & 19 & $\mathrm{~b}$ & 35.2 & $\mathrm{~b}$ & 47.8 & $\mathrm{a}$ & 56.4 & $\mathrm{~b}$ & 72 & $\mathrm{~b}$ \\
\hline \multirow[t]{2}{*}{$\mathrm{CV}(\%)$} & \multicolumn{12}{|c|}{24.15} \\
\hline & & & & & Math & quat & & & & & $\mathrm{R}^{2}$ & \\
\hline Blue screen & & & & -0.0 & $13 x^{2}+$ & 0.65 & -1.600 & & & & 97. & \\
\hline Red screen & & & & & 0.4616 & +0 . & 133 & & & & 91. & \\
\hline Black screen & & & & & $=0.485$ & $x+1$ & & & & & 96. & \\
\hline Full sunlight & & & & & $=0.368$ & $x+2$ & & & & & 93.3 & \\
\hline & & & & & Dry $m$ & ss of & ts + rhi & me & & & & \\
\hline Blue screen & 14.8 & $\mathrm{a}$ & 39.6 & $a$ & 69.2 & $\mathrm{a}$ & 78.2 & $\mathrm{a}$ & 188 & $\mathrm{a}$ & 277 & $\mathrm{c}$ \\
\hline Red screen & 22.8 & $\mathrm{a}$ & 33.3 & $\mathrm{a}$ & 52.8 & $\mathrm{a}$ & 66.2 & $\mathrm{a}$ & 138 & $\mathrm{~b}$ & 331.6 & $\mathrm{~b}$ \\
\hline Black screen & 22.8 & $\mathrm{a}$ & 30.3 & $\mathrm{a}$ & 74.4 & $\mathrm{a}$ & 58.8 & $\mathrm{a}$ & 198 & $\mathrm{a}$ & 387.2 & $\mathrm{a}$ \\
\hline Full sunlight & 16 & $\mathrm{a}$ & 20.2 & $\mathrm{a}$ & 52.6 & $\mathrm{a}$ & 64.3 & $\mathrm{a}$ & 113.2 & $\mathrm{~b}$ & 290 & $\mathrm{bc}$ \\
\hline CV (\%) & & & & & & & 64 & & & & & \\
\hline & & & & & Math & quat & & & & & $\mathrm{R}^{2}$ & \\
\hline Blue screen & & & & $=0.0$ & $27 x^{2}-$ & 993. & 41.5990 & & & & 97. & \\
\hline Red screen & & & & $=0.0$ & $59 x^{2}-$ & 403 & 33.8778 & & & & 92. & \\
\hline Black screen & & & & $=0.0$ & $88 x^{2}-$ & .5978 & $35.010^{7}$ & & & & 93. & \\
\hline Full sunlight & & & & $=0.0$ & $376-1$ & 1951 & 27.6263 & & & & 92. & \\
\hline
\end{tabular}

*Means followed by the same letter in the column do not differ significantly, as determined by the Tukey test ( $p>0.05)$.

*ns = not significant.

There was no statistical difference in the number of days from the issuance of the shoot until the collection of floral stems (CYCLE) between treatments (Table 3), The group of $H$. psittacorum $\times$ H. spathocircinata has been classified by Castro (1993) as a short cycle hybrid, which reaches the point of harvest in a period of less than 150 days after the issuance of shoots, a period shorter than that by other groups. Genotypes with short periods between the issuance of shoots and harvest of inflorescences are of interest because the floral stems are less exposed to damage in the field, and additionally enable frequent production of plant products from plants that produce throughout the year (COSTA et al., 2007). 
Table 3. Cycle, total number of floral stems (NFS Total), number of floral stems per square meter (NFS m$\left.{ }^{-2}\right)$, average floral stem length (FSL in $\mathrm{cm}$ ), floral stem diameter (FSD in $\mathrm{cm}$ ) and percentage of stems with marketing standard (SMS) of Heliconia psittacorum $\times$ H. spathocircinata 'Golden Torch' grown under different conditions (blue screen, red screen, black screen, and full sunlight) and assessed over a period of 180 days. Period: November 2013 to May 2014. Juazeiro, BA.

\begin{tabular}{lccccccccccc}
\hline & \multicolumn{1}{c}{ CYCLE } & \multicolumn{2}{c}{ NFS Total } & \multicolumn{2}{c}{ NFS m $^{-2}$} & FSL $(\mathrm{cm})$ & \multicolumn{2}{c}{ FSD $(\mathrm{cm})$} & \multicolumn{2}{c}{ SMS (\%) } \\
\hline Blue screen & 133 & $\mathrm{a}$ & 171 & $\mathrm{ab}$ & 85.5 & $\mathrm{ab}$ & 66 & $\mathrm{ab}$ & 0.74 & $\mathrm{a}$ & 47.5 \\
Red screen & 131.5 & $\mathrm{a}$ & 150 & $\mathrm{~b}$ & 75 & $\mathrm{~b}$ & 62 & $\mathrm{~b}$ & 0.73 & $\mathrm{a}$ & 30 \\
Black screen & 127 & $\mathrm{a}$ & 182 & $\mathrm{a}$ & 91 & $\mathrm{a}$ & 69 & $\mathrm{a}$ & 0.74 & $\mathrm{a}$ & 42.5 \\
Full sunlight & 126 & $\mathrm{a}$ & 103 & $\mathrm{c}$ & 51.5 & $\mathrm{c}$ & 54 & $\mathrm{c}$ & 0.73 & $\mathrm{a}$ & 7.5 \\
\hline \multicolumn{1}{c}{ CV(\%) } & 8.72 & 11.23 & \multicolumn{2}{c}{10.5} & 15.59 & 13.28 & & \\
\hline
\end{tabular}

*Means followed by the same letter in the column do not differ significantly, as determined by the Tukey test $(\mathrm{p}>0.05)$.

The number of floral stems harvested (NFS) is a well-appreciated variable, since the higher productivity may represent a higher number of marketable products. A significant difference was observed in the number of floral stems (NFS total), with a higher number being observed in plants raised under black screens, followed by plants grown under blue screens, red screens, and full sunlight (Table 3). This indicates that differences in luminosity affect not only the morphology and physiology of plants but also have an important impact on productivity, particularly because plant development requires appropriate light intensity. A lower percentage of luminosity is beneficial for the production of floral stems, whereas the excessive light intensity experienced by heliconia grown in full sunlight may prevent photosynthesis in the plants, thus reducing productivity (SONG et al., 2012) (Figure 1).

The number of inflorescences $/ \mathrm{m}^{2} \quad\left(\mathrm{NFS} / \mathrm{m}^{2}\right)$ produced under blue and black screens (Table 3) was statistically higher than that observed under the other conditions. The lowest number of inflorescences $/ \mathrm{m}^{2}$ was observed in plants produced in full sunlight $\left(51.5 / \mathrm{m}^{2}\right)$, which is probably due to reduced development of plants due to excessive light intensity and smaller shoots when compared to plants grown under the other conditions.

According to Castro (1995), plants of the species H. psittacorum are recommended for cultivations because they produce light and erect inflorescences. The average production of inflorescences in this species, under the conditions of the Ceará, is 130 stems $/ \mathrm{m}^{2}$ in the first year. In an experiment carried out in Porto Velho-RO, which has an average annual temperature of $25^{\circ} \mathrm{C}$, Rodrigues (2010) gathered 78 inflorescences $/ \mathrm{m}^{2}$ in 12 months of cultivation and 86 inflorescences $/ \mathrm{m}^{2}$ in 15 months of cultivation in full sunlight.

The lower number of inflorescences $/ \mathrm{m}^{2}$ obtained in the present study, compared with those obtained by Castro (1995), can be explained not only by the age of the plants, but also by the climatic conditions and the design of the experiment. It is worth emphasizing that only plants grown in full sunlight did not yield a satisfactory number of inflorescences, and that the productivity of plants grown under black screens (91) and blue screens (85.5) was superior to that described by Rodrigues (2010) at 12 months of cultivation.

Plants grown under black and blue screens also displayed higher flower stem length (FSL), being statistically superior to that of plants grown under the other conditions. The data from the present study are consistent with those of Nomura et al. (2009), who also obtained the best results for stem length of Anthurium andraeanum 'Apalai' in plants grown under black screens. The length of flower stalks is one of the standards of quality observed in the marketing of heliconias, since stem shortness imposes limitations on their use in floral arrangements, and they are accordingly devalued in the market (LOGES et al., 2005). 
Figure 1. Climatic conditions under different shading (blue screen, red screen, black screen, and full sunlight) during the cultivation of Heliconia psittacorum $\times$ H. spathocircinata 'Golden Torch'. Period: November 2013 to May 2014. Juazeiro, BA. A: Total daily solar radiation $\left(\mathrm{MJ} \mathrm{m}^{-2} \mathrm{day}^{-1}\right)$; B: average daily air temperature $\left({ }^{\circ} \mathrm{C}\right)$.

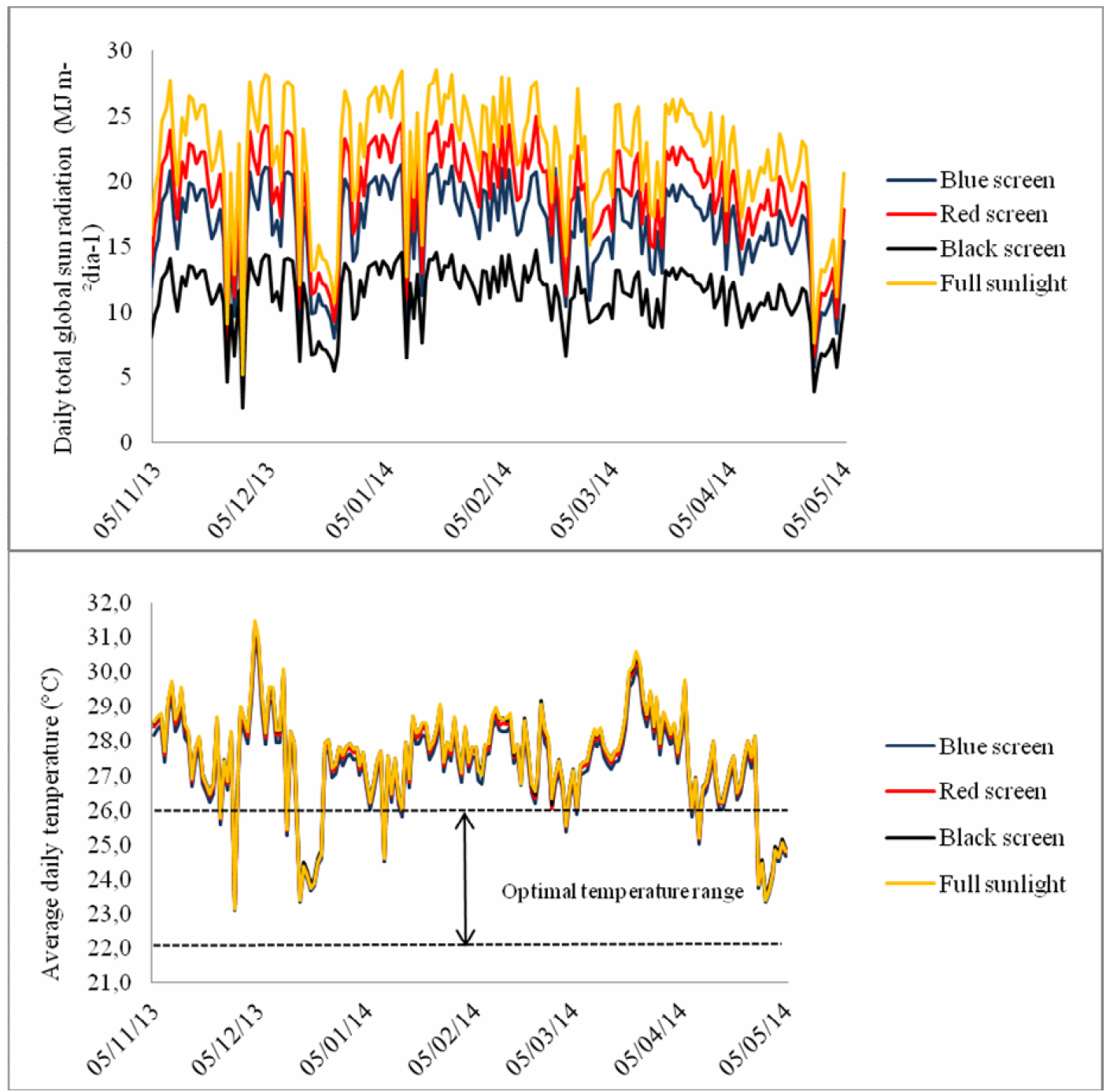

In contrast to flower stem length, the diameter of the flower stalks (FSD) showed no statistical difference between plants grown under the different conditions (Table 3). However, the observed values of $0.70 \mathrm{~cm}$ are satisfactory, as they are consistent with the diameter required for marketing $(0.70 \mathrm{~cm})$, as asserted by Lamas (2002) and Farias (2004).

The diameter and length of the stem are of great importance in the resistance of the flower to winds while growing in the field, during transport from the field to the treatment site, and throughout selection, packaging, and post-harvest periods. In general, in cut flowers the carbon reserves contained in the stem are used to extend the longevity potential of flowers, and the greater the length and diameter of the stem, the greater the durability after harvest (HERMANS et al., 2006; CASTRO et al., 2007).

With regards to commercial yield, plants grown under black and blue screens produced a larger percentage of floral stems within the specified standard of quality (Table 3), which is in agreement with the results of Nomura et al. (2009), who also obtained a higher quantity of marketable stems of Anthurium andraeanum 'Apalai' from cultivation under black screens. 
According to the literature, plants of 'Golden Torch' heliconia can be grown under half shade and/or full sunlight (BROSCHAT; DONSELMAN, 1986; CATLEY; BROOKING, 2006; COSTA et al., 2006). However, given the results obtained, it is noted that the commercial yield of heliconias grown in full sunlight, in areas of a high incidence of solar radiation, and consequently high temperatures, such as in the region of Juazeiro, BA, does not meet a standard of quality comparable to that of plants produced under shading screens. In terms of global solar radiation during the experiment, the total maximum daily radiation for cultivation under black, blue, and red screens was 14.7, 21.4, and $25 \mathrm{MJ}$ $\mathrm{m}^{-2}$ day $^{-1}$, respectively, whereas that in full sunlight reached 28.5 $\mathrm{MJ} \mathrm{m}^{-2}$ day $^{-1}$ (Figure 1A). Average values for the period were as follows: black screen, 11.2 $\mathrm{MJ} \mathrm{m}^{-2}$ day ${ }^{-1}$; blue screen, 16.5 $\mathrm{MJ} \mathrm{m}^{-2}$ day $^{-1}$; red screen, 19.0 $\mathrm{MJ} \mathrm{m}^{-2}$ day $^{-1}$; and full sunlight, 22.0 $\mathrm{MJ} \mathrm{m}^{-2}$ day $^{-1}$. The environment under the red screen showed a daily total global solar radiation close to that observed in full sunlight, which explains the lower productivity under this condition compared to that under black and blue screens.

The higher availability of energy in non-shaded areas might have affected the development of vegetation and the quality of the floral stems. Plants grown in full sunlight had smaller size and stem length compared to plants grown under shading, as well as a high incidence of stems with breaks and whitish coloration (visual data).

One point to be highlighted is that, in terms of average daily temperature during the experiment, the variation between conditions was very small, with a minimum of $23.1{ }^{\circ} \mathrm{C}$ and maximum of 31.5 ${ }^{\circ} \mathrm{C}$ (Figure 1B). The average daily temperatures for the entire period were 27.5, 27.2, 27.4, and $27.5{ }^{\circ} \mathrm{C}$ for the conditions under black, blue, and red screens, and full sunlight, respectively. In other words, on most days, during the experiment, the average daily temperature under the different conditions was higher than the upper limit of the range considered optimal (between 22 and $26{ }^{\circ} \mathrm{C}$ ) for the production of 'Golden Torch' heliconia, indicated by Cattley and Brooking (1996). In spite of these higher average daily temperatures, the shaded environments, mainly under black and blue screens, provided floral stems within the standard of quality required for the crop. It appears, therefore, that the reduction in luminosity, produced mainly by the black screens ( $50 \%$ shading), provided a favorable microclimate for the production of a higher number of longer floral stems.

\section{Conclusion}

Our results show that the use of black and blue screens are indicated for the production of 'Golden Torch' heliconia because they provide greater production and higher rates of floral stems at standard sizes for commercialization.

\section{References}

ALBUQUERQUE, A. W.; ROCHA, E. S.; COSTA, J. P. V.; FARIAS, A. P.; BASTOS, A. L. Produção de Helicônia Golden Torch influenciada pela adubação mineral e orgânica. Revista Brasileira de Engenharia Agricola e Ambiental, Campina Grande, v.1 4, p. 10521058, 2010. Disponível em: <http://www.scielo.br/pdf/ rbeaa/v14n10/v14n10a05.pdf $>$. Acesso em: 07 jun. 2016.

BROSCHAT, T. K.; DONSELMAN, H. Tropical cut flower at the University of Florida's Ft. Lauderdade. Bulletin of the Research and Education Center, Ft. Lauderdale, v. 2, n. 2-3, p. 5-6, 1986.

CASTRO, C. E. F. Heliconias como flores de corte: adequação de espécies e tecnologia pós-colheita. 1993. Tese (Doutorado) - Escola Superior de Agronomia Luiz de Queiroz, Universidade Federal de São Paulo.

Heliconias para exportação: aspectos técnicos da produção. Brasília, Embrapa-SPI, 1995. 44 p. (Publicações Técnicas Frupex, 16).

CASTRO,A. C. R.; LOGES, V.; COSTA, A. S.; CASTRO, M. F. A.; ARAGÃO, F. A. S.; WILLADINO, L. G. Hastes florais de heliconia sob deficiência de macronutrientes. Pesquisa Agropecuária Brasileira, Brasília, v. 42, p. 1299-1306, 2007. Disponível em: <http://www.scielo.br/ pdf/pab/v42n9/12.pdf $>$.Acesso em: 07 jun. 2016. 
CATTLEY, J.; BROOKING, I. Temperature and light influence growth and flower production in Heliconia 'Golden Torch'. Hortscience, Alexandria, v. 31, p. 213-217, 1996. Disponível em: <http://hortsci. ashspublications.org/content/31/2/213.full.pdf > . Acesso em: 07 jun. 2016.

CRAVEN, D.; GULAMHUSSEIN, S.; BERLYN, G. P. Physiological and anatomical responses of Acacia koa (gray) seedlings to varying light and drought conditions. Enviromental and Experimental Botany, Oulu, v. 69, n. 69, p. 205-213, 2010. Disponível em: $<$ http://www.sciencedirect.com/science/article/pii/ S0098847210000791>. Acesso em: 07 jun. 2016.

CRILEY, R. A.; MACIEL, N.; FU, Z.; UCHIDA, J. Productivity of three heliconia hybrids. Heliconia Society International Bulletin, Kalaheo, v. 10, n. 3, 2001. Disponível em: <http://media.wix.com/ugd/eflaa2_ ebf7e84d31c548dc8ba556b06b1b951a.pdf >. Acesso em: 07 jun. 2016.

COSTAA. S.; LOGES V.; CASTRO, A. C. R.; VERONA, A. L.; PESSOA, C. O.; SANTOS, V. F. Perfilhamento e expansão de touceiras de helicônias, Horticultura Brasileira. Brasília, v. 24, p. 460-463. 2006. Disponível em: <http://www.scielo.br/pdf/\%0D/hb/v24n4/13.pdf>. Acesso em: 07 jun. 2016.

COSTA, A. S.; LOGES, V.; CASTRO, A. C. R.; BEZERRA, G. J. S. M.; SANTOS, V. F. Variabilidade genética e correlações entre caracteres de cultivares e híbridos de Heliconia psittacorum, Revista Brasileira de Ciências Agrárias, Recife, v. 2, p. 187-192, 2007. Disponível em: <http://www.agraria.pro.br/sistema/ index.php?journal=agraria\&page $=$ article $\&$ op $=$ view\&pa th $\% 5 \mathrm{~B} \% 5 \mathrm{D}=100 \&$ path $\% 5 \mathrm{~B} \% 5 \mathrm{D}=112>$. Acesso em: 09 maio 2015.

DAY, Y. J.; SHEN, Z. G; LIU, Y.; WANG, L.; HANNAWAY, D.; LU, H. Effects of shade treatments on the photosynthetic capacity, chlorophyll fluorescence, and chlorophyll content of Tetrastigma hemsleyanum Diels et Gilg, Environmental and Experimental Botany, Alexandria, v. 65 p. 177-182, 2009. Disponível em: $<$ http://www.sciencedirect.com/science/article/pii/ S0098847208001603>. Acesso 07 jun. 2016.

FARIAS, A. P. Componentes de produção da H. Golden Torch (Helicônia psittacorum x H. spathocircinata) influenciada pela adubação mineral e orgânica. 2004. Dissertação (Mestrado) - Centro de Ciências Agrárias/ Universidade Federal de Alagoas.

FAVARETTO, V. F.; MARTINEZ, C. A.; SORIANI, H. H.; FURRIEL, R. P. M. Differential responses of antioxidant enzymes in pioneer and late-successional tropical tree species grown under sun and shade conditions. Environmental and Experimental Botany, Alexandria, v. 70, p. 20-28, 2011. Disponível em: $<$ http://www.sciencedirect.com/science/article/pii/ S0098847210001437>. Acesso em: 07 jun. 2016.

GAFFNEY, M. ChromatiNet-light spectrum management. Greenhouse Product News, Arlington Heights, v. 14, n. 12, p. 54, 2004.

HART, J. W. Light and plant growth. London: Unwin Hyman, 1988. 204 p.

HERMANS, C.; HAMMOND, J. P.; VERBRUGGEN, N. How do plants respond to nutrient shortage by biomass allocation? Trends in Plant Science, Cambridge, v .11, p. 610-617, 2006.

HOLCMAN, E.; SENTELHAS, P.C. Bromeliads production in greenhouses associated to different shading screens. Horticultura brasileira, Brasília, v. 31, n. 3, p. 386-391, 2013. Disponível em: <http://www.scielo.br/ pdf/hb/v31n3/08.pdf $>$. Acesso em: 07 jun. 2016.

ILIĆ, Z. S.; MILENKOVIĆ, L.; STANOJEVIEĆ, L.; CVETKOVIĆ, D.; FALLIK, E. Effects of the modification of light intensity by color shade nets on yield and quality of tomato fruits. Scientia Horticulturae, Tsukuba, v. 139, p. 90-95, 2012. Disponível em: $<$ http://www.sciencedirect.com/science/article/pii/ S0304423812001331>. Acesso em 07 jun. 2016.

KAWABATA, A. F.; LICHTY, J. S. KOBAYASHI, K. D.; SAKAI, W. S. Effects of photoselective shade cloths on potted Dracaena deremensis' Janet Craig' and Dracaena marginata 'Colorama'. Journal of Hawaiian and Pacific Agriculture, Hilo, v. 14, p. 49-54. 2007. Disponível em: $\quad<$ http://hilo.hawaii.edu/panr/writing.php?id=165>. Acesso em 07 jun. 2016.

LAMAS, A. M. Floricultura tropical: técnicas de cultivo e pós colheita de flores e folhagens. Fortaleza: Instituto Frutal. 2002. 135 p.

LAMAS, A. M. F. Flores: produção, pós-colheita e mercado. Fortaleza: Instituto Frutal, 2004.109 p.

LIMA, J. D.; NOMURA, E. S.; FUZITANI, E. J.; MODENESE-GORLA DA SILVA, S. H. Variáveis fisiológicas de Antúrio cultivado sob diferentes malhas de sombreamento. Scientia Agraria, Curitiba, v. 3, n. 11, p. 193-200, 2010. Disponível em: <http://ojs.c3sl.ufpr. br/ojs/index.php/agraria/article/viewFile/17232/11498>. Acesso em: 07 jun. 2016.

LOGES, V. Heliconia agronomic characteristics for use as cut flowers and ornamental plant: research developed in Pernambuco, northeast part of Brazil. Heliconia Society 
International Bulletin, Kalaheo, v. 18, n. 4, p. 2- 5, 2012. Disponível em: <http://www.heliconia.org/\#!2012 Vol 18. No. 4/zoom/clnv/image_cxq $>$. Acesso em: 07 jun. 2016.

LOGES, V.; TEIXEIRA, M. C. F.; CASTRO, A. N. R.; COSTA, A. S. Colheita, pós-colheita e embalagem de flores tropicais em Pernambuco. Horticultura Brasileira, Brasília, v. 23, n.3, p. 699-702, 2005. Disponível em: $<$ http://www.scielo.br/scielo.php?script=sci_arttext\&pid $=$ S0102-05362005000300001>. Aceso em 07 jun. 2016.

MEIRELlES, A. J. A.; PAIVA, P. D. O.; OLIVEIRA, M. I.; TAVARES, T. S. Influência de diferentes sombreamentos e nutrição foliar no desenvolvimento de mudas de palmeira ráfia Rhapis excelsa (Thunberg) Henry ex. Rehder. Ciência e Agrotecnologia, Lavras, v. 6, n. 3, p. 1884-1887, 2007. Disponível em: $\quad<$ http://www.scielo.br/scielo.php?pid=S1413$70542007000600043 \&$ script $=$ sci_arttext $>$. Acesso em: 07 jun. 2016.

NOMURA, E. S.; LIMA, J. D.; RODRIGUES, D. S.; GARCIA, V. A.; FUZITANI, E. J.; MODENESEGORLA DA SILVA, S. H. Crescimento e produção de antúrio cultivado sob diferentes malhas de sombreamento. Ciência Rural, Santa Maria, v. 5, n. 39, p. 1394-1400. 2009. Disponível em: <http://www.scielo.br/pdf/cr/ v39n5/a14v39n5.pdf $>$. Acesso em: 07 jun. 2016.

OREN-SHAMIR, M.; GUSSAKOVSKY, E. E.; SHPIEGEL, A.; NISSIM-LEVI, A.; RATNER, K.; OVADIA, R.; GILLER, Y. E.; SHAHAK, Y. Coloured shade nets can improve the yield and quality of green decorative branches of Pittosporum variegatum. Journal of Horticultural Science and Biotechnology, Oxford, v. 76, n. 3, p. 353-361, 2001.
OYAERT, E.; VOLCKAERT, E.; DEBERGH, P. C. Growth of chrysanthemum under coloured plastic films with different light qualities and quantities. Scientia Horticulturae, Tsukuba, v. 79, p. 195-205, 1999. Disponível em: <http://www.sciencedirect.com/science/ article/pii/S0304423898002076>. Acesso em: 07 jun. 2016.

RODRIGUES, V. G. S. Recomendações técnicas para a propagação deflores tropicais em Rondônia. EMBRAPA, 2007. (Circular técnica, 328).

Avaliação de cultivares de Heliconia pssittacorum nas condições de Porto Velho, Rondônia. EMBRAPA, 2010. (Circular técnica, 117).

SONG, R.; KELMAN, D.; JOHNS, K. L.; WRIGHT, A. D. Correlation between leaf age, shade levels, and characteristic beneficial natural constituents of tea (Camellia sinensis) grown in Hawaii. Food Chemistry, Reading, n. 133, p. 707-714, 2012. Disponível em: $<$ http://www.sciencedirect.com/science/article/pii/ S0308814612001306>. Acesso em: 07 jun. 2016. doi: 10.1016/j.foodchem.2012.01.078.

SOUZA, R. R. D. Desenvolvimento inicial e pós-colheita de alpínia. 2012. Tese (Doutorado em Agronomia Produção Vegetal) - Universidade Federal de Lavras. Lavras.

TAIZ, L.; ZEIGER, E. Fisiologia vegetal. 5. ed. Porto Alegre: Artmed, 2013. 954 p.

VALE, F. X. R.; FERNANDES FILHO, E.; LIBERATO, J. R. Quantificação de doenças - Quant: versão 1.0.1. Viçosa: UFV, 2001. (Software). 
